\title{
ILLUSORY RESTITUTION OF NOT PRESERVED ARCHITECTURAL OBJECTS - AN ANALYSIS OF METHODS AND A CASE STUDY
}

\author{
ILUZORYCZNA RESTYTUCJA NIEZACHOWANYCH OBIEKTÓW \\ ARCHITEKTONICZNYCH - ANALIZA METOD I STUDIUM PRZYPADKU
}

\author{
Maciej Piekarski \\ dr hab. inż. \\ ORCID: 0000-0002-9788-1099
}

\section{Ewa Kulpińska}

mgr inż. arch.

ORCID: 0000-0001-9709-3095

Anna Prokop

mgr inż. arch.

ORCID: 0000-0003-2666-1002

Politechnika Rzeszowska

Wydział Budownictwa, Inżynierii Środowiska i Architektury

Zakład Projektowania Architektonicznego i Grafiki Inżynierskiej

\begin{abstract}
The article concerns the illusory presentation of non-existent architectural objects directly in the place of their original location. This specific conservation method is considered as a tool for disseminating knowledge about the original architectural landscape of places where it has undergone transformations. The authors believe that its implementation may contribute to the growth of the identity of cities and their inhabitants. The concept refers to augmented reality, but the authors use only optical means to create a virtual component, The article presents the results of theoretical analysis and practical experiments, pointing to the advantages and disadvantages of the method.
\end{abstract}

Key words: conservation methods, city identity, augmented reality.

\section{STRESZCZENIE}

Artykuł dotyczy iluzorycznej prezentacji nieistniejących obiektów architektonicznych bezpośrednio w miejscu ich pierwotnej lokalizacji. Ta swoista metoda konserwatorska jest rozpatrywana jako narzędzie upowszechniania wiedzy o pierwotnym krajobrazie architektonicznym miejsc, w których uległ on przekształceniom. Autorzy uważają, że jej implementacja przyczyni się do wzrostu tożsamości miast i ich mieszkańców. Koncepcja odwołuje się do rzeczywistości rozszerzonej, lecz autorzy do kreowania komponentu wirtualnego używają środków wyłącznie optycznych. Artykuł przedstawia rezultaty analizy teoretycznej i eksperymentów praktycznych, wskazując na walory i mankamenty metody.

Słowa kluczowe: metody konserwatorskie, tożsamość miasta, rzeczywistość rozszerzona. 


\section{INTRODUCTION}

Urban development usually is not only limited to a territorial expansion and the development of previously undeveloped areas but is accompanied by the transformation of the architectural and urban structure of the previously occupied space. The changes take place as a result of the transformation of road systems but also as a result of the replacement of architectural objects that are worn out due to their technical condition or their functions not being adjusted to the current needs. Significant transformations in the space of some cities are the result of war destruction as well as changes in the nationality of the city or the ethnic structure of its residents. Removing landmarks raises nostalgia in the minds of people who identify with the city. The authors believe that inversely - spreading the information about the former appearance of the city to the residents who have no knowledge about its urban development and anchoring it in their awareness may result in increased identification with the city which becomes a significant value from the point of view of shaping a local community.

The sources of knowledge about the city's former landscape are archival documents and photographs. In the Internet era, the availability of them is relatively easy. However, the Internet resource is usually queried in a place other than the location of the observed objects. Therefore, the imaginative linking of the photography scenery with the contemporary arrangement of the same space requires predisposition and familiarity with the city. According to the authors, an illusory in situ restitution, which relies on presentation of unpreserved architectural objects on the background of their contemporary surroundings perceived directly, can facilitate this mental process. From the point of view of the classifications of conservation methods (Tomaszewski 2012) it locates as between the restoration and documentation-based conservation. The illusory presentation of the essential properties of an architectural work would provide compensation for its material absence and is sufficient to assess the value of this work (Ingarden 1958).

\section{AUGMENTED REALITY IMPLEMENTATION IN ARCHITECTURE}

\subsection{Augmented reality concept}

The link between the real and the illusory world is defined as mixed reality. The definitions of mixed reality (MR) as well as augmented reality (AR) and augmented virtuality (AV) were introduced in the 1990' $s$ and referred to the linkage of the real world with computer-generated components (Caudell \& Mizell 1992, Millgram et al. 1994). According to a refinement formulated afterward (Azuma 1997) augmented reality provides parallel observation of the real world with the virtual objects imposed on it, which complements the real world but does not replace it. The hallmarks of augmented reality are the combination of virtual reality with the real world, real-time interactivity, and localization of virtual objects in three-dimensional space.

The essence of augmented reality is the co-presence of real objects and intangible representations of these objects. The involvement of computer technology is not essential to qualify presentation of space that fulfils the aforementioned condition as augmented reality (Konik 2011). Instead of electronic devices, the optical devices can be used, or representation of virtual components can be done without using any technical equipment but only by using formal means appropriate for generating the illusion (Piekarski 2018).

\subsection{Classification of augmented reality systems}

Augmented reality systems can be classified according to the following criteria (Piekarski 2018):

- type of used technology: optical or electronic;

- degree of immersion of the user in the perception of the virtual environment that is different when using Window-On-the-World (WOW) or Head-Mounted-Displays (HMD) devices;

- way of combining virtuality and reality (observing an image of the real environment through a camera or with the unaided eye);

- characteristics of the generated image (mono- or stereoscopic);

- way of locating projection devices (stationary or mobile). 


\subsection{Determinants of augmented reality applications in architectural spaces}

Augmented reality technology can be used in architecture for visualizing objects currently designed, to preventive determine their impact on the landscape (Konopacki 2014a, Mazur et al. 2019), or as a means of reminiscence of architectural objects removed from the landscape (Konopacki 2014b, Piekarski 2018). In this article, the considerations focus on the second case. The elimination of an architectural object causes that the space left after it remains empty or is filled with a new, usually larger object. For the in situ restitution the first situation creates more favourable conditions. The presence of other architectural objects in the considered space is the factor influencing the quality of restitution. If these objects co-existed with the restituted one and photographs depicting them together are preserved, this helps to establish the precise location and dimensions of the non-existing object. Each presence of other objects in the surrounding area makes it easier for the observer to relate the virtual component to the real environment.

The rationality of illusory in situ restitution depends on the precision of visualizing the location and size of the restituted objects. This is supported by projecting the image of the virtual component using stationary devices, especially eyeglasses, forcing the observation from a strictly defined place in space. For this purpose, the use of optical technology is sufficient. The computer technology can provide an omnidirectional view of an object. However, the necessity to process a realtime image based on changing geolocation data by a mobile device, which computing power is limited, puts into question the quality and accuracy of the restitution. Moreover, the image of the real component displayed on the mobile device is less natural than perceived directly, especially since it is only a copy of the image in the observer's field of view, extending beyond the monitor of the device. The appropriate selection of observation positions is important regarding the accuracy of the information provided especially about the object's scale (Dordevic \& Vujic 2010).

\section{ILLUSORY RESTITUTION BY OPTICAL MEANS}

\subsection{Assumptions}

The intention of the authors is not to accurately represent the architectural objects removed from space but only to provide information about their location, size, and outline of the shape. The observer should perceive mainly the actual environment surrounding him against the background of which the image of the once existing objects - determinants of the lost landscape - is less clear. It has been considered that optical means have an advantage over electronic ones for such illusory restitution.

The image of the virtual component should be transparent or translucent so as not to obscure existing buildings and moving people or vehicles. This movement may take place at a distance from the observer greater than the distance of the restituted object or in the space between the observer and the object. The lack of sufficient transparency of the image of virtual component can nullify illusion at all. Using stereoscopic image-generating means should have a beneficial effect on the illusory reconstruction of the object.

The experiment specified that the basic form of the virtual component image would be a linear representation. Very subdued filling of the linear image is accepted considering that it can have a useful effect on the representation of the object's solidity. Invisible lines are not marked. Their presence counteracts the observer from tuning the sense of sight to perceive the scene correctly. The image of the virtual component should be monochromatic so that it does not bring additional perceptual difficulties. When presented in gray shades it will bring associations with black and white photographs, identifying the past.

It was determined that the projections of the virtual component will be constructed directly based on the principle of centre projection, by using AutoCAD. The models of restored objects, models of necessary objects for calibration of the view, the background of the central projection, and the position of the observer's eye will be created in the virtual space. The position was assumed to be 1.5 $\mathrm{m}$ above the ground. The projection corresponding to the one-eyed view is defined by the points of 
intersection with the background plane of a set of projecting lines drawn from the observer's eye in the direction of the model vertices. For stereoscopic mapping, the construction should be repeated by shifting the centre of the second projection towards the centre of the first projection in the direction horizontal and parallel to the background by a distance of $65 \mathrm{~mm}$, considered equal to the pupil distance in adults (Mączyńska-Frydryszek et al. 1991).

\subsection{Monoscopic restitution}

Monoscopic restitution consists of placing the image of a virtual component on a transparent board. The distance between the observer and the board should be adjusted so that the drawing fits on a sheet of A4 size and at the same time is located entirely within the central field of view which according to (Mączyńska-Frydryszek et al. 1991) includes a vertex angle of $40^{\circ}$. Reducing the image size of the virtual component is to prevent the incompatibility of the confluence points obtained by construction based directly on the central projection with the vanishing points perceived directly. It appears when the observer is forced to move the eyeballs not being able to cover the entire slice of space of interest with one fixed gaze (Strzemiński 1958).

The image should be viewed with one eye. To get a true impression of the location and size of the restored object it is necessary to reproduce selected fragments of the current environment to calibrate the image. The observer should also be shown where to stand.

\subsection{Stereoscopic restitution}

\subsubsection{Application of anaglyphs}

Anaglyphs are drawings that provide a three-dimensional impression when viewed through special glasses. This is achieved because the drawing consists of separate projections of the object for the left and right eye. Each one of them is drawn with a line of a different colour and the glasses tinted each one in different colours, work as filters eliminating the colours not addressed to the specific eye. One of the practical applications of anaglyphs, invented by Wilhelm Rollmann back in 1853 (Kaenders \& Weiss 2017), is to aid the teaching of descriptive geometry. Several authors have included sets of anaglyphs in their textbooks (Otto \& Otto 1980, Przewłocki 1983) to help the readers to understand not very intelligible planimetric mappings.

The operation of the filters in anaglyph glasses is based on the colour theory (Drew \& Meyer 2013). According to additive theory, the colour space, known by the RGB abbreviation, is described by three elementary colours: red $(R)$, green $(G)$, and blue $(B)$. The intensity of each colour is specified by an integer between $\langle 0,255>$. A mixture of $R, G$, and $B$ colours each having a value of 255 produces white light. Alternatively, it can be achieved by combining only two colours: the first of values $R=x, B=y, G=z$ and the second of values $R=255-x, B=255-y, G=255-z$. Such a colour pair is called complementary colours [20]. The application of a colour filter results in filtering out the light of the filter colour and absorption of light of a colour complementary to the filter colour (Weissenbock \& Symeonidou 2019).

Additive colour theory refers to the blending of lights. Colour mixing in printing is done according to subtractive colour theory (Drew \& Meyer 2013). In the colour space according to this theory called CMYK, the elementary colours are cyan $(\mathrm{C})$, magenta $(\mathrm{M})$, yellow $(\mathrm{Y})$, and black $(\mathrm{K})$. The intensity of each colour is specified as an integer between $<0,100>$. Any chosen colour can be obtained without the contribution of black because it is a combination of $\mathrm{C}, \mathrm{M}$, and $\mathrm{Y}$ colours with values of 100 each. The concept of complementary colours is analogous to the RGB model. Also, for each of the colours constituting the RGB colour space, equivalent colours can be determined in the CMYK space and vice versa. Calculators for numerical conversions are available on the Internet (RapidTables). In the context of anaglyphs, it is possible to determine the colours of the print adequate for the eye filters used. In practice, CMYK-based colours tend to diverge quite significantly from their RGB-based counterparts.

In the most commonly used variant of the anaglyph technique the projection for the left eye is plotted in azure $(C=100, M=0, Y=0)$ and the projection for the right eye is plotted in red $(C=0, M=100$, 
$Y=100)$. For viewing the drawing, the glasses in which the left filter is red $(R=255, G=0, B=0)$ and the right filter is azure $(R=0, G=255, B=255)$ are used. The pairs of complementary colours are the colours of both filters, the colours of both projections, and pairs consisting of the colour of the filter and the colour of the projection dedicated to it. Each eye can only the projection that is plotted in a colour different than the filter through which the eye is looking. The sum of the colour of the filter and the colour of the drawing seen through it is according to subtractive colour theory always the black colour. The drawing providing the impression of three-dimensionality is visible as black and sits in the middle between projections plotted in red and azure, which remain invisible (Fig. 1).

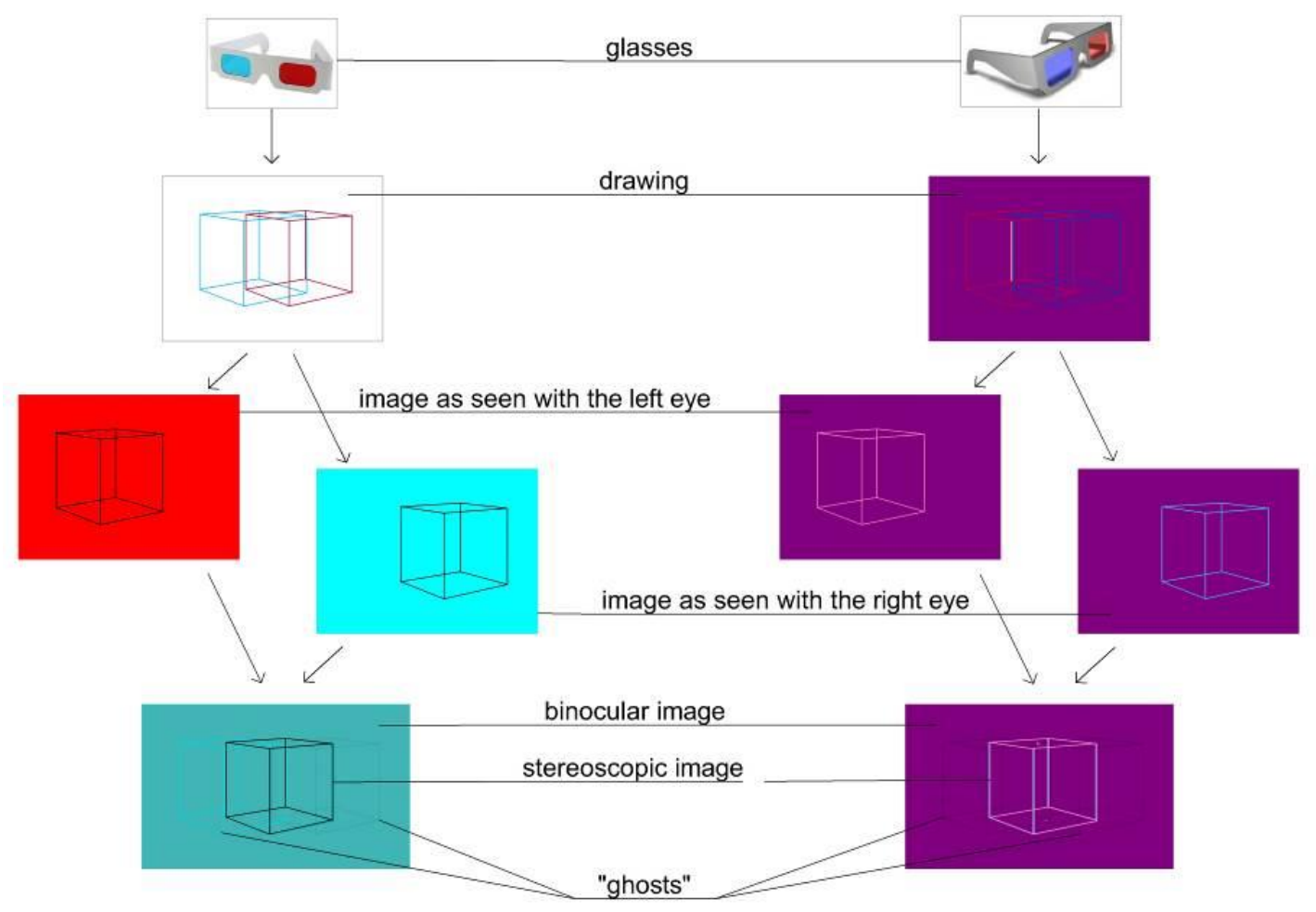

Fig. 1. Two methods of creating anaglyphs. Source: own work

Ryc. 1. Dwie metody tworzenia anaglifów. Żródło: opracowanie własne

An issue that poses great difficulty is the appearance of ghosts, which are images of those projections that should be filtered out by an appropriate filter. The ghosts appear at the locations of the plotted projections, except that they are less clear than them, and also less clear than the spatial image. However, they co-form with it a triad of images, making it difficult for the observer to concentrate on perceiving the correct one. Ghosting is the result of a change of the colour of the filter exposed to light toward white colour. In the filter colour, apart from those RGB colour values that are specific to the material used in the filter, the values of complementary colours increase, which means that the colours from the CMYK model that should be filtered out are not completely filtered out.

A technique in which the colours of the filters and projections are chosen so that the red line is visible through the red filter and the blue line is visible through the blue filter, while the blue line is made invisible by the red filter and the red line is made invisible by the blue filter, is a certain way of solving the ghost problem. Implementation of this method requires that the projections for the left and right eye are not on a white background, but on a background with a colour, which is an ap- 
propriately selected mixture of $\mathrm{C}, \mathrm{M}$, and $\mathrm{Y}$ colours. The workbook with anaglyphs respecting such assumptions was attached to the textbook (Otto \&Otto 1980). The glasses with a red filter for the right eye $(R=255, G=0, B=0)$ and a blue filter for the left eye $(R=0, G=0, B=255)$ have been used. Since the red filter absorbs only colour $\mathrm{C}$ and the blue filter absorbs only colour $\mathrm{Y}$, the projections should be plotted with lines whose colours show residual absorbed components in addition to the filtered components, i.e. $\mathrm{M}$ and $\mathrm{Y}$ for red and $\mathrm{C}$ and $\mathrm{M}$ for blue: $\mathrm{C}$ in red colour and $\mathrm{Y}$ in blue colour. In fact, neither the red filter filters out the $\mathrm{C}$ colour, nor the blue filter of the $\mathrm{Y}$ colour, but only the subtractive mixing of the filter colours cause that unwanted projection images to become indistinguishable from the background. Ghosting is not an issue in this technique because even if ghosts are created by "overexposure" of the filters, their colour is similar to the background (Fig. 1).

Using anaglyphs to project a virtual component in augmented reality requires an analogous technical means as for monoscopic restitution i.e. a transparent board with pairs of colour projections of the object. The remarks mentioned in section 3.2 about the position of the observer and the fragmentary representation of objects from the environment are also applicable. Due to the role of colours and the transparency of the materials, the quality of the restitution may additionally depend on the exposure conditions resulting, among others, from the state of insolation.

\subsubsection{The use of stereoscope}

The stereoscope provides an impression of three-dimensionality thanks to the fact that like in anaglyphs other specially prepared images are viewed with the left and right eyes. They are close to the observer eyes, but the structure of the stereoscope prevents the left eye to observe the image dedicated to the right eye and vice versa. The impression that both images are located in the same place is achieved by using a system of lenses refracting the directions of light rays. The stereoscope, invented by Charles Weathstone in 1832 (Blundell 2011), became very popular in photoplasticons - devices allowing for presentation of series of stereoscopic images simultaneously to a wider audience.

Adaptation of a traditional stereoscope for use with augmented reality technology requires that the material used to present the pair of images of the virtual component is transparent. As a consequence of the necessity of lenses the combined perception of these images with the image of the real environment is not possible without extending the device with an additional optical system. In the place where the traditional stereoscope places non-transparent drawings plotted separately for the left and right eye, the adapted device should include a screen made of translucent material on which the image of the real environment and the plotted image of the virtual component would be displayed.

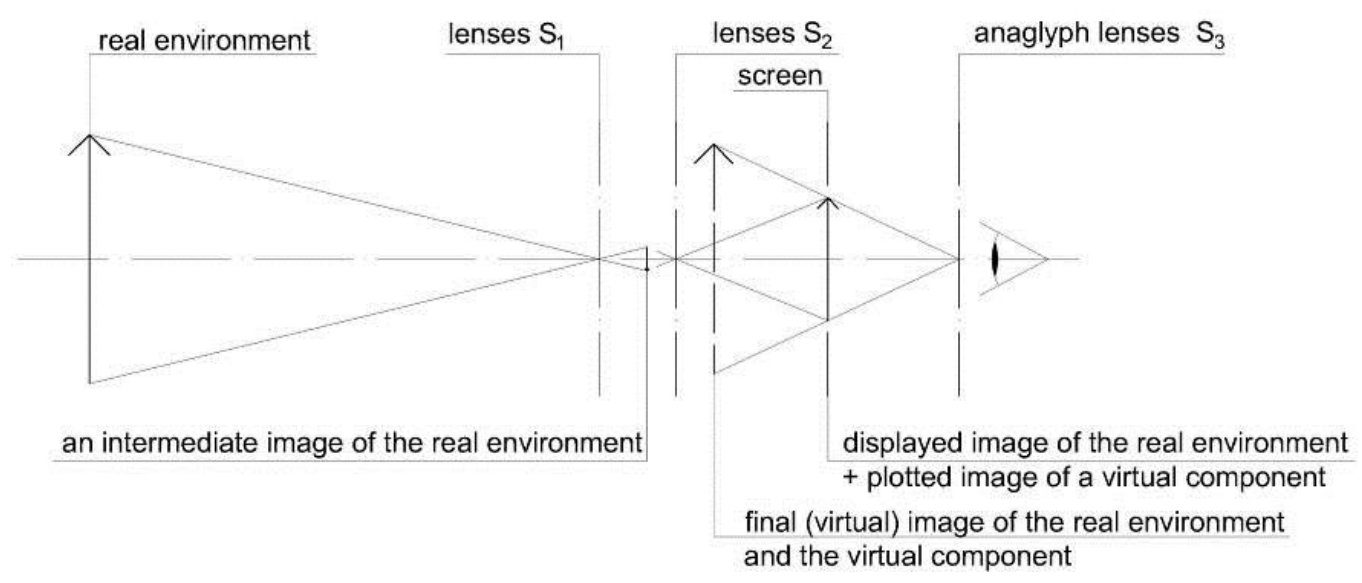

Fig. 2. Schematic of a stereoscope adapted to an augmented reality environment. Source: own work

Ryc. 2. Schemat stereoskopu adaptowanego do środowiska rzeczywistości rozszerzonej. Źródło: opracowanie własne 
A scheme of the stereoscope adapted according to the above description is shown in Fig. 2. A pair of lenses $S_{1}$ inverts and diminishes separate images viewed with the left and right eye and then they are inverted and magnified with lenses $S_{2}$. The described effect is achieved if lenses $S_{1}, S_{2}$, and $S_{3}$ and the screen are placed at distances satisfying conditions resulting from basic principles of geometrical optics (Hecht 2012), explained in the figure in functions of lens focal lengths marked $f_{1}, f_{2}$, and $f_{3}$ respectively. Choosing these focal lengths is also influenced by the presumed size of the device. Images transformed by the $\mathrm{S}_{2}$ lenses are projected onto a screen of translucent material on which the virtual component images are located. The overlapping actual images of both augmented reality components are then perceived by the observer analogously to a traditional stereoscope.

\section{DESCRIPTION OF THE CONDUCTED RESEARCH}

\subsection{Restitution of a geometric figure in an interior - calibration of a method}

During the first phase of the experiment a cube of the $1 \mathrm{~m}$ edge length was restituted. The restitution was performed indoors with the observer facing a glass wall to make the lighting conditions as similar as possible to those in an open space. The board was placed at a distance of $5 \mathrm{~m}$ from the nearest edge of the cube, and the observer was placed at a distance of $0.55 \mathrm{~m}$ in front of the board. A projection had been constructed according to the procedure described in Section 3.1. Anaglyphs has been constructed according to the same procedure, shifting the centre of the second projection relative to the centre of the first projection $65 \mathrm{~mm}$ along a line horizontal and parallel to the board (Fig. 3).

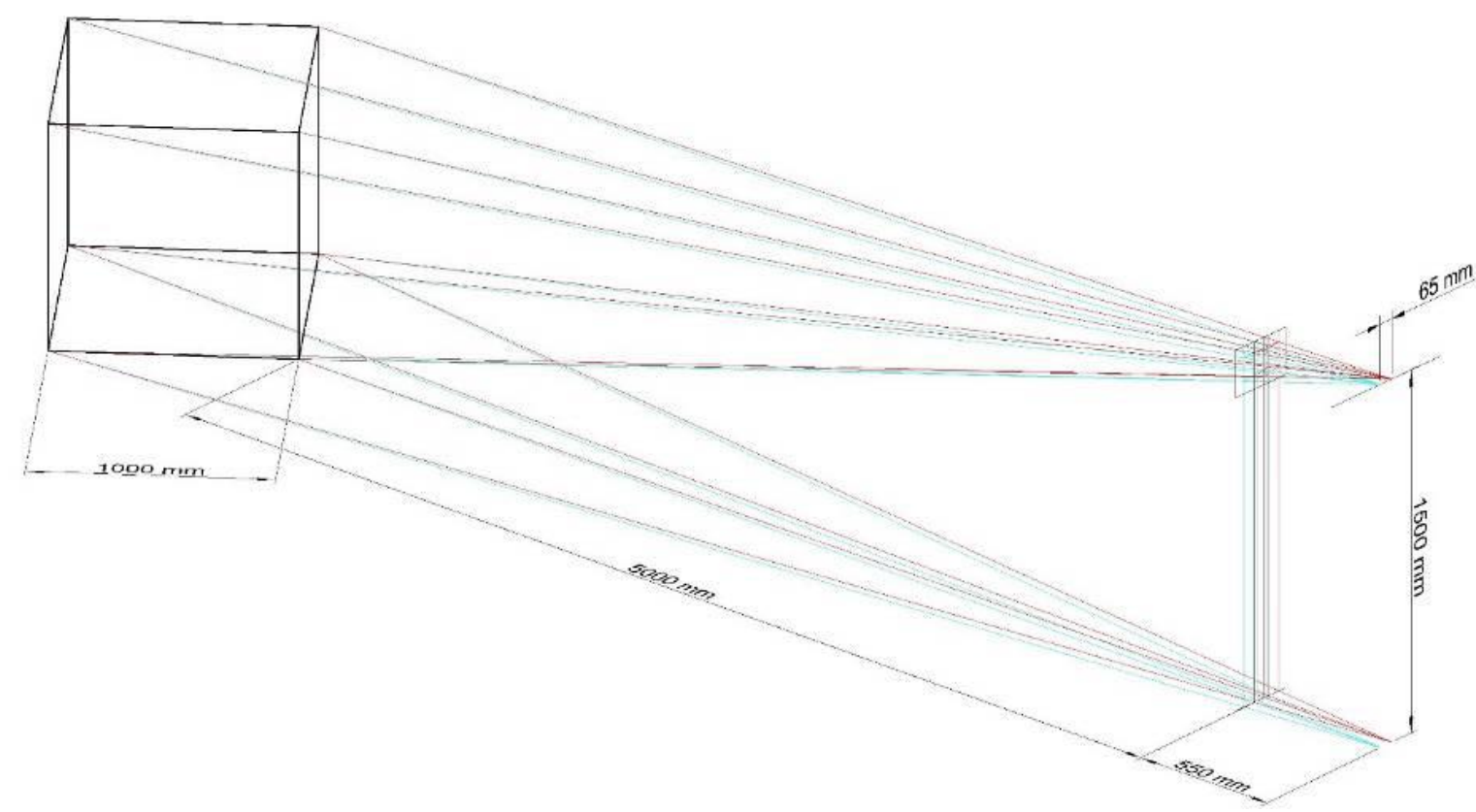

Fig. 3. Construction of anaglyph projections of the cube. Source: own work

Ryc. 3. Konstrukcja rzutów anaglifowych sześcianu. Źródło: opracowanie własne

The test began with a monoscopic image. To verify the accuracy of the figure location restitution, a $1 \mathrm{~m}$ square was marked on the floor of the room with coloured tape. Figure size, resulting from location of the object, the board, and the observer, turned out to be accurate and concerns de- 
scribed in section 3.2 were unfounded (Fig. 4a). Further confirming the rationality of the method, the cube projection was completed with projections of elements of the environment, to verify that the calibration of the observer's position based on images of characteristic lines in the real environment is sufficiently accurate. In the intended application of the method in architectural space, the location of the virtual component will not be marked. Also this hypothesis was verified successfully (Fig. 4b).

a)

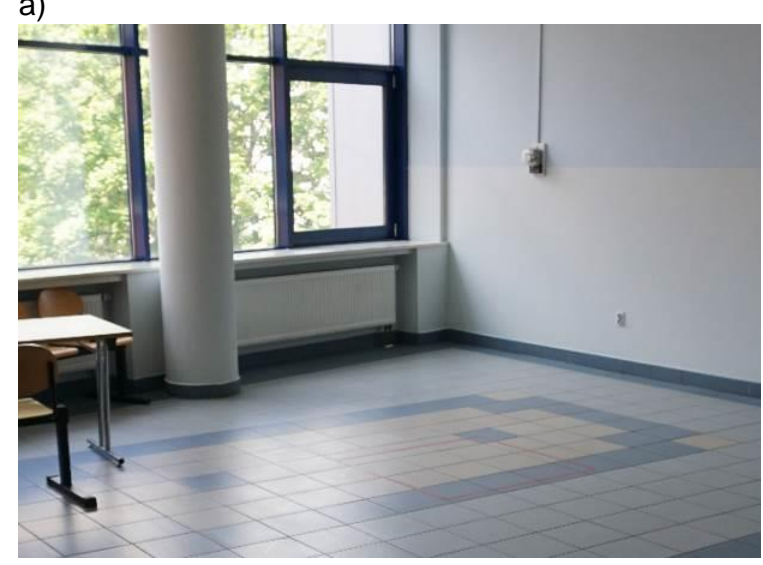

b)

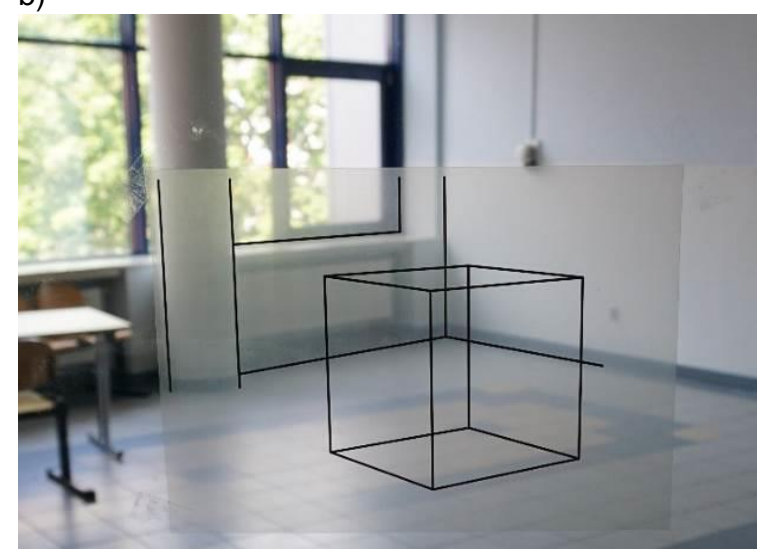

Fig. 4. Cube illusory restitution validation using a monoscopic image: a) based on marking the object location, b) based on projections of characteristic lines in the environment. Source: own photos

Ryc. 4. Weryfikacja poprawności restytucji iluzorycznej sześcianu za pomocą obrazu monoskopowego: a) w oparciu o zaznaczenie położenia obiektu, b) w oparciu o rzuty charakterystycznych linii w otoczeniu. Źródło: fotografie własne

Further, the images differing in colour (black and red), line thickness $(0.35,0.7$, and $1.0 \mathrm{~mm}$ ), and drawing form limited to linear figure or enriched with fill of 20,40 , and $60 \%$ level, were observed. The black drawing has been found more favourable effect than the red one. Out of the three-line thicknesses, a line thickness of $0.7 \mathrm{~mm}$ was selected for further experimentation. The drawing with filling has been found as a good alternative to line picture, and an infill of $40 \%$ has been chosen for experiments in architectural space.

The monoscopic image has been taken into account in the experiment because it does not require special glasses so it is available to everyone in the public space, but the better results were expected from stereoscopic images. With the same mutual position of the object, the board, and the observer, an illusory restitution test based on anaglyphs was performed. The projections for the left and right eyes were plotted with $0.7 \mathrm{~mm}$ thick lines, with colours derived from the relationships described in Section 3.3.1.

Anaglyphs made as intended for the first variant of the method i.e. plotted on a colourless background with lines in azure and red, met expectations only to a limited extent. The first complication turned out to be the difficulty in "tuning" the visual organ encountered by few external persons asked to take part in the experiment. The problem is that visual acuity should be tuned to the observation of the object at its presumed location, while those announcing their inability to see the stereoscopic image, despite explanations from the authors, were probably concentrating on observing the board on which the cube projections were located. A second complication is the appearance of ghosts. Ghosts' appearance is the result not only of the colour change of filters illuminated by ambient light but also of the colour change of the drawing itself, which is plotted on transparent material. 
Also, a trial was made with the anaglyphs drawn on a dark background. The fact that the background is not colourless, in the opinion of the authors is not in itself an issue. However, the printed background on a transparent foil was not transparent enough to allow a satisfactory perception of the environment behind the anaglyph board. Consequently, there is a difficulty in correlating the image of the virtual component with the image of the real environment. This test was repeated using anaglyphs plotted against a less intense background colour, but there was no improvement in the resulting quality. Using coloured foil instead of colourless can't be considered, because the colour of the foil would also affect the colours of the anaglyphs printed on it. In this variant of anaglyphs, the presence of ghosts is also a disadvantage. Despite a coloured background, their appearance is due to the change of colour of the background as a result of backlighting by ambient light.

The experiment with the projection of the image of the virtual component using a stereoscope did not give satisfying results due to the insufficient transparency of the screen, made of tracing paper, with the simultaneous low brightness of the image, resulting from the optical system used. This system was implemented as shown in the figure 2 . The lenses used were $S_{1}$ with a focal length of $30 \mathrm{~mm}$ and $\mathrm{S}_{2}$ with a focal length of $15 \mathrm{~mm}$. Typical lenses used in cardboard stereoscopes and devices known as Google Cardboard were used as $S_{3}$ lenses and a distance $d_{31}$ (Fig. 2) of $70 \mathrm{~mm}$ was assumed identical to that in these devices. The selection of the parameters of the optical system was determined by the availability of lenses and the initial assumed approximate size of the device.

\subsection{Experiment verification in architectural space}

The conclusions of the visualization of the cube were verified in architectural space. It was decided that the object of illusory restitution would be the so-called 'The Red Gate Inn' - a building located in Rzeszów on Grunwaldzka Street, demolished in the 1950s in connection with the construction of the Provincial Office Building (UW) in the neighbourhood. Because the demolition of the building took place only after the completion of the construction of the UW, available photographs show together two buildings (Fig. 5). This is circumstance that facilitates restitution; another is the vacant space left at the site of Inn. The choice of this building was considered appropriate also because of its architectural form, which being relatively simple, was also quite original.

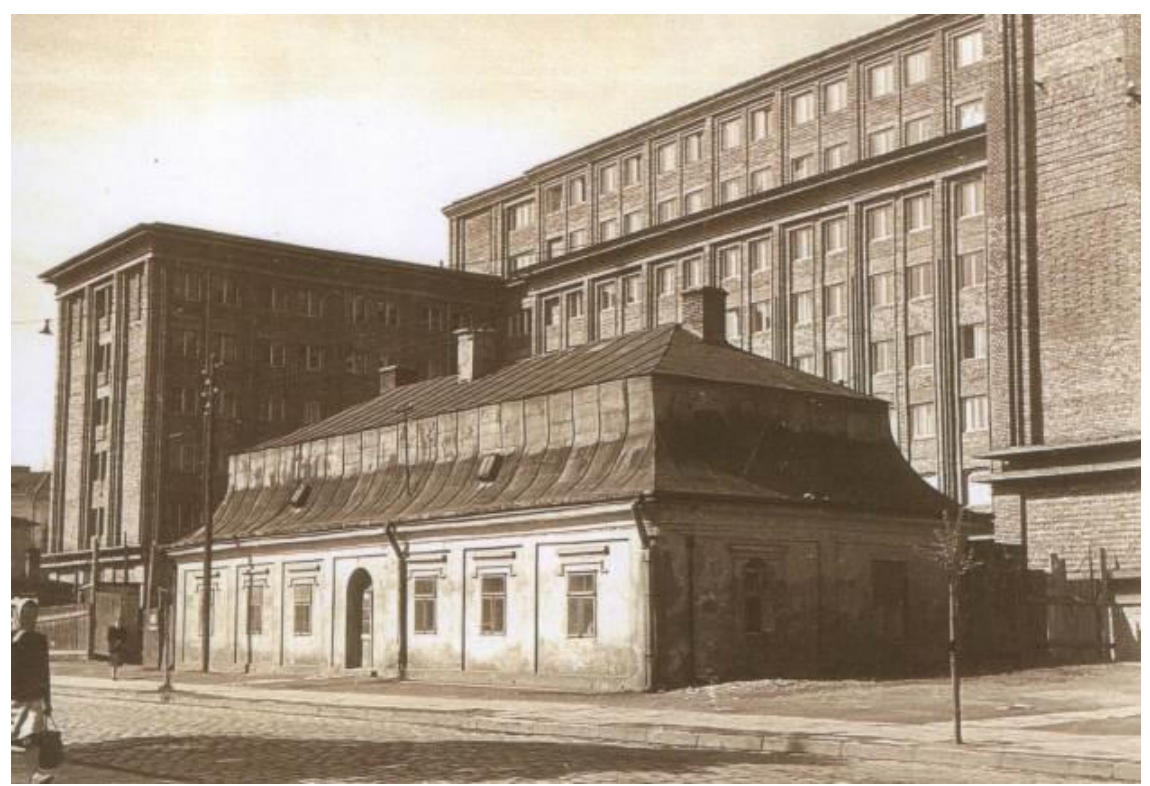

Fig. 5 The Red Gate Inn on Grunwaldzka Street in Rzeszow. Source: own archival resource

Ryc. 5 Zajazd pod Czerwoną Bramą przy ul. Grunwaldzkiej w Rzeszowie. Źródło: własny zasób archiwalny 


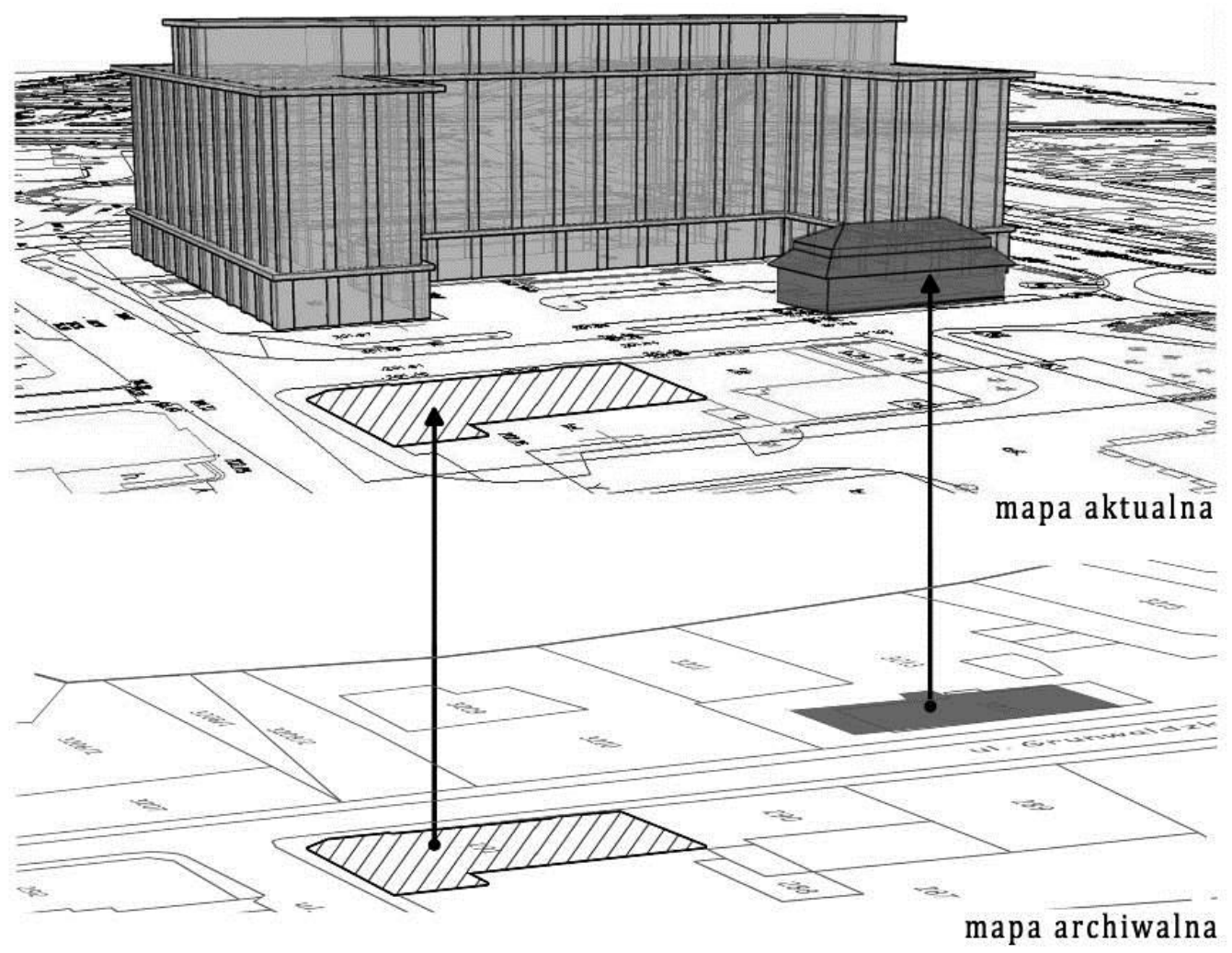

Fig. 6. Scheme of the reconstruction of the location of The Red Gate Inn. Source: own work

Ryc. 6. Schemat rekonstrukcji położenia budynku Zajazdu pod Czerwoną Bramą. Źródło: opracowanie własne

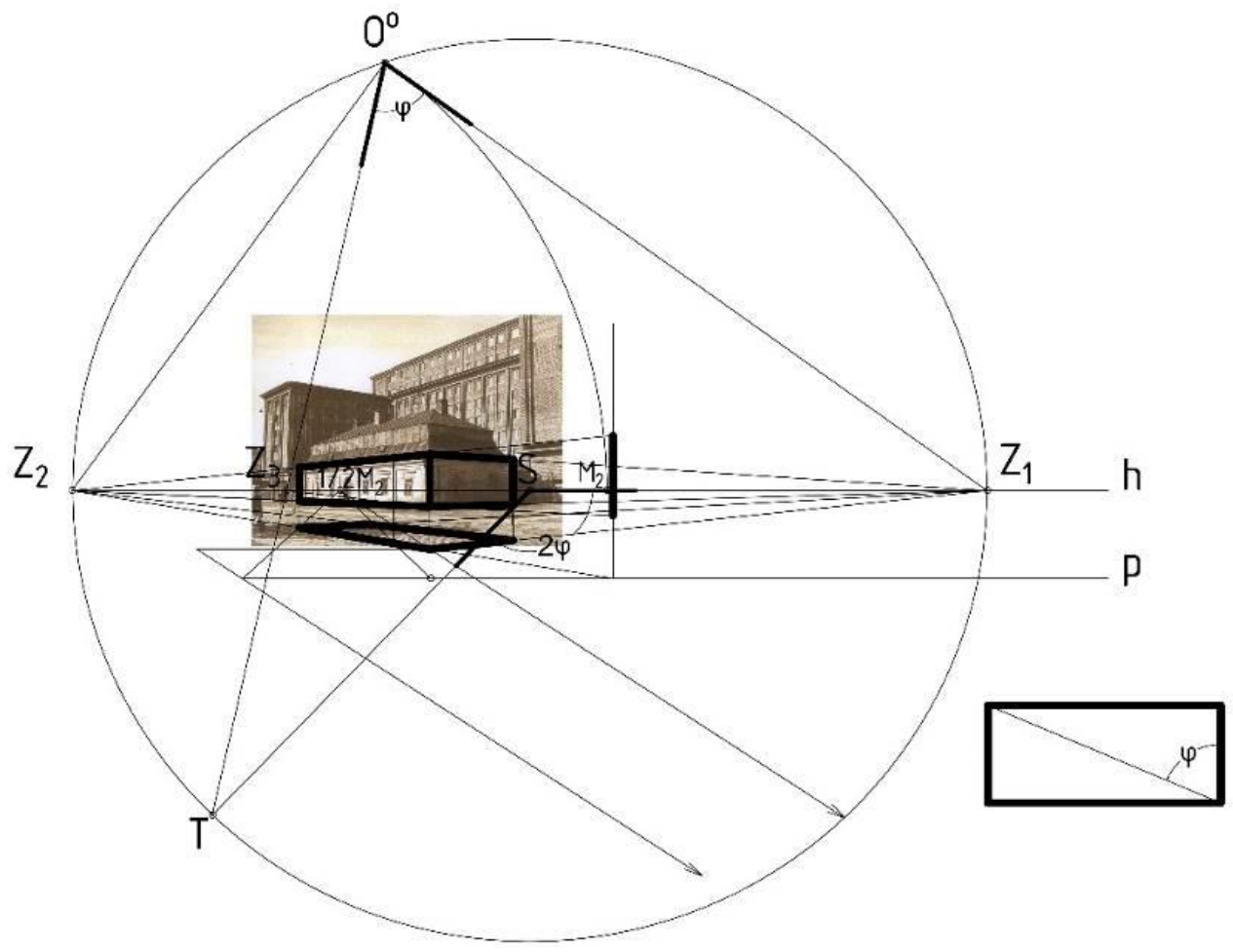

Fig. 7. Scheme of the reconstruction of the dimensions of The Red Gate Inn. Source: own work

Ryc. 7. Schemat rekonstrukcji wymiarów budynku Zajazdu pod Czerwoną Bramą. Źródło: opracowanie własne 
The 3D model was prepared in AutoCAD. The location of the Inn has been found from the map older than the UW building. Since it was assumed that the UW building would be the reference for the observer, it was necessary to impose the archival map to the current one (Fig. 6). It was easy due to the existence of objects in the neighbourhood, which have not changed over the years. The remaining dimensions of the Inn have been reconstructed on the basis of the photography. The perspective construction was drawn on it using data from the building plan (Grochowski 2010). This procedure is explained in Fig. 7. The UW building model is based on data from the current map, measurements made in situ and measurements from the Digital Land Cover Model (NMPT).

The spatially related three-dimensional models of the buildings of the Inn and the UW enables the construction of both objects views from any point in space. The illusory restitution has been performed from two points providing essentially different views of the Inn (Fig. 8) using the methods as for the cube restitution. The experiment was repeated several times under different lighting conditions. Images of the virtual component were subjected to corrections taking into account observations made during previous trials.

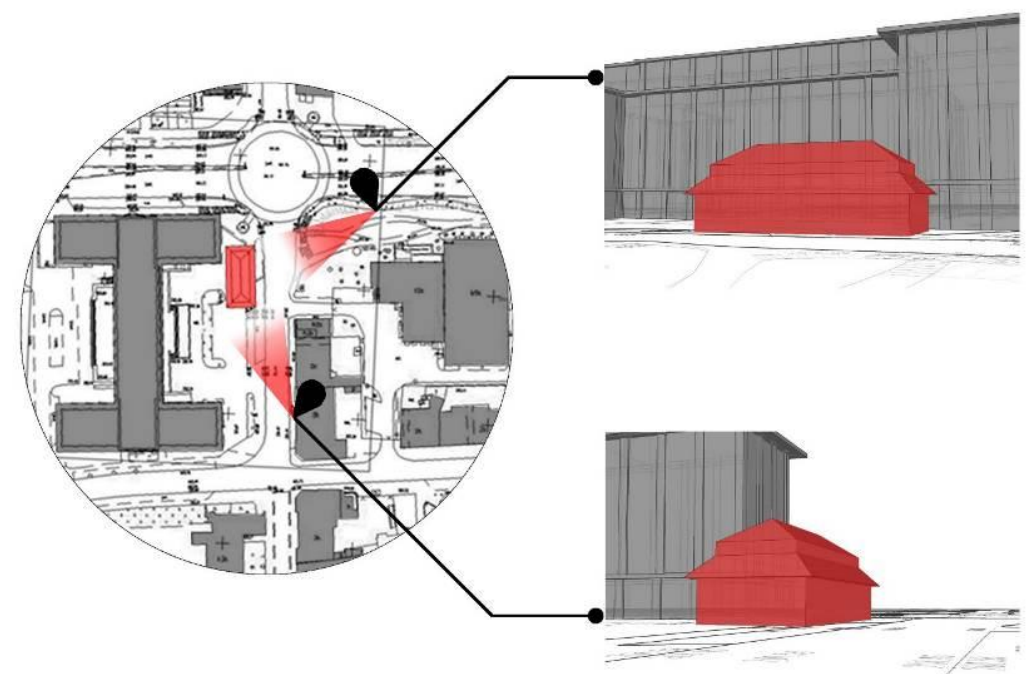

Fig. 8. Perspective views of The Red Gate Inn from selected observation points. Source: own work

Ryc. 8. Rzuty perspektywiczne Zajazdu pod Czerwoną Bramą z wybranych punktów obserwacji. Źródło: opracowanie własne

\subsection{Description of the results}

The lighting conditions have the greatest impact on the quality of restitution in open area. Strong sunlight is unfavourable for methods using a transparent board. Depending on the sun position, the clarity of the material is reduced or light reflections appear (Fig. 9a).

The variability of lighting conditions is particularly problematic for anaglyphs. Because of the brightening of colours under the sunlight, the inconsistency between the colours of filters and drawings deepens, and the clarity of the ghosts increases. More favourable results are achieved if the observation site is shaded, when it is cloudy, or during the time when the projection of sunlight is limited. The black 3D image is much clearer on the bright background. The contrast between the threedimensional image and the background is then greater than that between the ghosts and the background, so they do not distract from the three-dimensional image. (Fig. 9b). 
a)

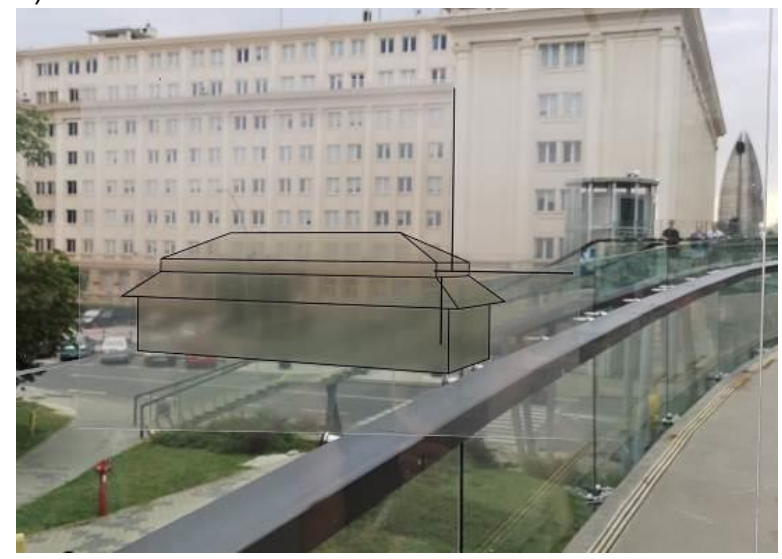

b)

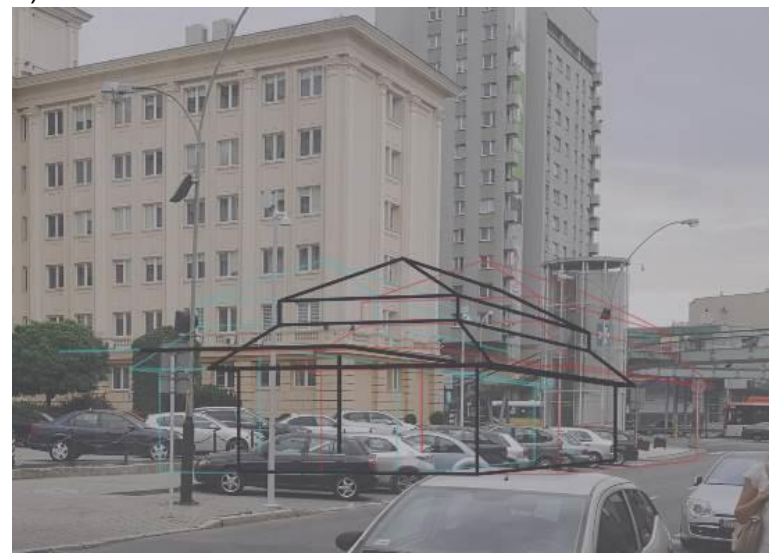

Fig. 9. Illusory restitution of The Red Gate Inn: a) monoscopic image b) simulation of an anaglyph image viewed through red and azure glasses against a bright background. Source: a) own photo, b) own work

Ryc. 9. Restytucja iluzoryczna Zajazdu pod Czerwoną Bramą: a) obraz monoskopowy b) symulacja obrazu anaglifowego oglądanego przez okulary czerwono-błękitne na jasnym tle. Źródło: a) fotografia własna, b) opracowanie własne

Although anaglyphs printed on a dark background make it difficult to perceive the real environment, the principle on which they are based can also be used on a colourless background. Good effects are obtained when the role of the dark background is taken over by a dark building facade or a group of shaded trees. In this case, the bright stereoscopic image contrasts with the background, while the ghosts similar in colour to the background disappear. The difference in contrasts focuses the observer's attention on the three-dimensional image. In the place where the experiment was carried out, there were no suitable conditions for using this method.

Another factor influencing the quality of perception is the location of elements calibrating the observer's position. They should be expressive in the perceived space, and located near the center of the field of view. Otherwise, the observer focuses on the search for calibration elements, not on the object of the illusory restitution. A requirement for success is position at the right distance from the board and to place the eyes at the right height. Although the place where the observer should stand can be marked, the correct distance of the feet from the base of the board does not guarantee the same distance of the observer's eyes from the image because man can adopt a posture not exactly vertical. Also locating the eyes at the correct level is difficult for people of different heights.

Despite authors' competence, subjects' perception of the stereoscopic image was not immediate. Perception of spatial depth requires attunement of the visual organ while concentration on the three-dimensionality problem weakens the intensity of attention on the elements calibrating the observer's position. For this reason, methods in which the position of the observer's eyes and the image of the virtual component are not unambiguously correlated give way to the use of a stereoscope in which each eye is directly adjacent to the eyepiece of a device that occupies a fixed position in space.

The stereoscope experiment was repeated in an open space. In good sunlight, when the image of the real environment became bright it turned out to be partially visible. The calibration of the instrument has proved to be difficult, especially due to the lack of clear contrasts in this image. The calibration process is, however, a one-off and, moreover, it can be supported by geodetic methods. The authors had a stereoscope mounted on a photographic tripod (Fig. 10), less stable than a device in the form of a small architecture object. The user relieved of calibration the position can focus only on accommodating the eyes to perceive the three-dimensional image. The partial opacity of the image can even be considered as an advantage. It reinforces the impression of the unreality of the interpenetration of non-simultaneous phases of space development which is unreal after all. 

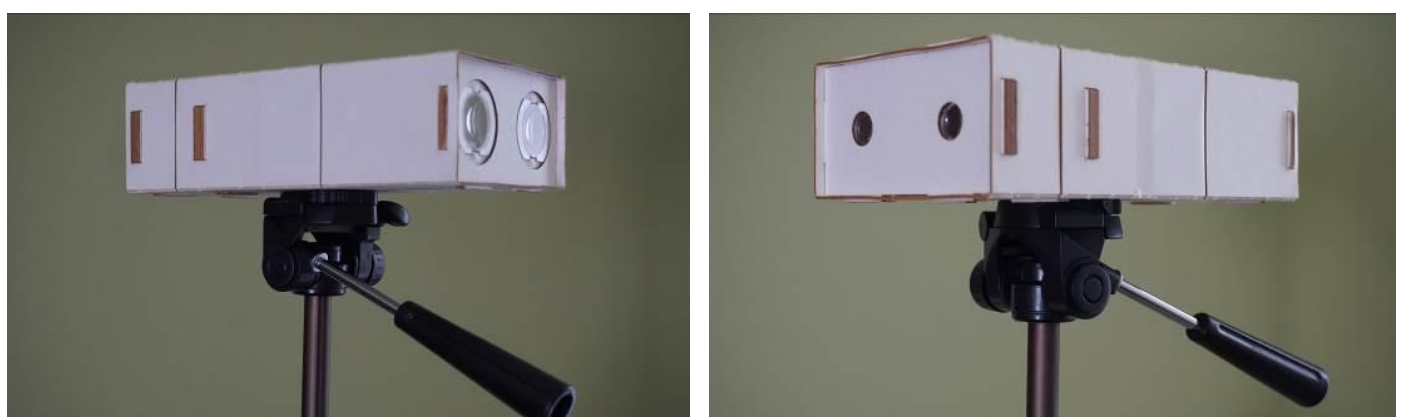

Fig. 10. The stereoscope used in the experiment. Source: own photos

Ryc. 10 Stereoskop używany w eksperymencie. Źródło: fotografie własne

\section{CONCLUSIONS FOR FURTHER RESEARCH}

The results obtained during the experiments guide the direction of further research. First of all, the deficiencies that result from inadequate parameters of the equipment, quality of materials, colours of prints, etc. should be eliminated. The improvement of the quality of images can and should become a starting point for researching a larger group of people who should be asked to evaluate the ways of illusory restitution, preferably on some measurable scale. The perception of a threedimensional image compiled from two two-dimensional images, as mentioned is not automatic even for people with developed spatial predispositions. Illusory restitution as an educational method is also addressed to a less prepared audience. Therefore, it is necessary to obtain an authoritative opinion before deciding on its application in public space.

The most difficult to solve is the ghosting problem in anaglyphs. It is widely emphasized in the literature (Ideses \& Yaroslavsky 2005, Woods et al. 2013), and even the most precise adjustment of the colour of the ocular filters and the drawing can produce an effect satisfying only under strictly defined lighting conditions. A remedy could be sought in electronic technology, based on the use of a transparent screen on which the colours of the anaglyphs would be corrected by an appropriate program with the colours of the ocular filters in real-time (Kim et al. 2011). Research in this area is at least for now beyond the technical capabilities and competence of the authors.

The authors prefer using old 19th-century optical techniques to visualize architectural objects whose existence is anchored in the past. However, there are no reasons preventing the implementation of modern technologies as well, especially if their effectiveness will be higher. Searching for the most perfect methods and tools of illusory restitution is also important in the context of an application for in situ visualizations of newly designed objects to preventively determine their influence on the existing architectural landscape.

\section{ILUZORYCZNA RESTYTUCJA IN SITU NIEZACHOWANYCH OBIEKTÓW ARCHITEKTONICZNYCH - ANALIZA PRAKTYCZNYCH ŚRODKÓW I STUDIUM PRZYPADKU}

\section{WPROWADZENIE}

Rozwój miasta nie sprowadza się tylko do ekspansji terytorialnej i zabudowy obszarów niezabudowanych. Towarzyszą mu zmiany struktury architektoniczno-urbanistycznej w obrębie dotychczasowego terytorium. Dokonują się one $w$ rezultacie przebudowy układów drogowych lub w związku z wymianą obiektów architektonicznych, które uległy zużyciu ze względu na stan techniczny lub 
niedostosowanie funkcji do aktualnych potrzeb. Istotne przeobrażenia w przestrzeni niektórych miast są rezultatem zniszczeń wojennych, zmiany przynależności państwowej miasta lub składu narodowościowego mieszkańców. Usunięcie obiektów charakterystycznych budzi tęsknotę w świadomości osób identyfikujących się z miastem. Autorzy uważają, że odwrotnie - dotarcie z informacją o przeszłym wyglądzie miasta do mieszkańców nie mających wiedzy o jego rozwoju przestrzennym, i zakorzenienie jej w ich świadomości, może skutkować wzrostem identyfikacji z miastem, która jest wartością bezcenną z punktu widzenia kształtowania wspólnotowości lokalnej.

Źródłami wiedzy o dawnym krajobrazie miasta są dokumenty archiwalne oraz fotografie. W dobie Internetu ich dostępność jest stosunkowo łatwa. Kwerenda zasobu internetowego prowadzona jest najczęściej w miejscu innym niż lokalizacja oglądanych obiektów. Wyobrażeniowe powiązanie scenerii starej fotografii ze współczesnym urządzeniem tej samej przestrzeni wymaga odpowiednich predyspozycji oraz pamięciowej znajomości miasta. Zdaniem autorów, iluzoryczna restytucja in situ, polegająca na prezentacji niezachowanych obiektów architektonicznych na tle postrzeganego bezpośrednio ich współczesnego otoczenia, może ułatwić ten mentalny proces. Z punktu widzenia klasyfikacji metod konserwatorskich (Tomaszewski 2012) lokuje się jako forma pośrednia pomiędzy odbudową konserwatorską a konserwacją przez dokumentację. Iluzyjne przedstawienie istotnych własności dzieła architektonicznego może stanowić rekompensatę jego materialnej nieobecności, wystarczającą dla oceny wartości tego dzieła (Ingarden 1958).

\section{ZASTOSOWANIE RZECZYWISTOŚCI ROZSZERZONEJ W ARCHITEKTURZE}

\subsection{Koncepcja rzeczywistości rozszerzonej}

Powiązanie świata rzeczywistego i pozornego jest nazywane rzeczywistością mieszaną. Definicje rzeczywistości mieszanej (ang. mixed reality - MR) oraz rzeczywistości rozszerzonej (ang. augmented reality - AR) i rozszerzonej wirtualności (ang. augmented virtuality - AV) pochodzą z lat 90-tych XX wieku i odnoszą się do powiązań świata rzeczywistego z komponentami generowanymi komputerowo (Caudell \& Mizell 1992, Millgram et al. 1994). Według późniejszego uściślenia (Azuma 1997), rzeczywistość rozszerzona zapewnia obserwację świata rzeczywistego z nałożonymi nań obrazami obiektów wirtualnych. Wyróżnikami rzeczywistości rozszerzonej są: połączenie rzeczywistości wirtualnej ze światem realnym, interaktywność w czasie rzeczywistym oraz lokalizacja obiektów wirtualnych w przestrzeni trójwymiarowej.

Istotą rzeczywistości rozszerzonej jest współobecność obiektów realnych oraz niematerialnych reprezentacji takich obiektów. Zaangażowanie technologii komputerowej nie jest konieczne, aby prezentację przestrzeni czyniącą zadość ww. warunkowi kwalifikować w kategorii rzeczywistości rozszerzonej (Konik 2011). Zamiast urządzeń elektronicznych mogą być stosowane urządzenia optyczne, lub przedstawienie komponentów wirtualnych może się dokonać bez wykorzystania środków technicznych, a jedynie za pomocą zastosowania środków formalnych odpowiednich dla wytworzenia iluzji (Piekarski 2018).

\subsection{Klasyfikacja systemów rzeczywistości rozszerzonej}

Systemy rzeczywistości rozszerzonej mogą być klasyfikowane wg następujących kryteriów (Piekarski 2018):

- rodzaju zastosowanej technologii: optycznej lub elektronicznej;

- stopnia wciągnięcia użytkownika w percepcję środowiska wirtualnego, różnego przy zastosowaniu urządzeń tablicowych (ang. Window-On-the-World-WOW) lub okularowych (ang. HeadMounted-Displays-HMD);

- sposobu syntezowania wirtualności i rzeczywistości (obserwacja obrazu środowiska rzeczywistego za pośrednictwem kamery lub okiem nieuzbrojonym);

- właściwości generowanego obrazu (mono- lub stereoskopowy);

- sposobu lokalizacji urządzeń projekcyjnych (stacjonarne lub mobilne). 


\subsection{Uwarunkowanie zastosowań rzeczywistości rozszerzonej w przestrzeni architektonicznej}

Technologia rzeczywistości rozszerzonej może być wykorzystywana w architekturze do wizualizowania obiektów aktualnie projektowanych w celu prewencyjnego określenia ich wpływu na krajobraz (Konopacki 2014a, Mazur et al. 2019) lub jako środek reminiscencji obiektów usuniętych z krajobrazu (Konopacki 2014b, Piekarski 2018). Rozważania w tym artykule dotyczą drugiego przypadku. Likwidacja obiektu architektonicznego powoduje, że przestrzeń po nim pozostaje pusta, albo zostaje wypełniona nowym, najczęściej większym obiektem. Dla restytucji in situ lepsze warunki stwarza pierwsza sytuacja. Czynnikiem mającym wpływ na jakość restytucji, jest obecność w sąsiedztwie innych obiektów architektonicznych. Jeżeli wspótistniały one z obiektem restytuowanym i zachowane są fotografie przedstawiające je wspólnie, to taka okoliczność pomaga w ustaleniu położenia i wymiarów nieistniejącego obiektu. Każda obecność innych obiektów w sąsiedztwie ułatwia obserwatorowi powiązanie komponentu wirtualnego ze środowiskiem rzeczywistym.

Racjonalność iluzorycznej restytucji in situ zależy od precyzji wizualizowania lokalizacji i rozmiarów restytuowanych obiektów. Sprzyja jej projekcja obrazu komponentu wirtualnego za pomocą urządzeń stacjonarnych, zwłaszcza okularowych, wymuszających obserwację z określonego miejsca w przestrzeni. Dla realizacji tego celu wystarczające jest zastosowanie technologii optycznej. Technologia komputerowa może zapewnić dookolny ogląd obiektu. Jednak konieczność przetwarzania w czasie rzeczywistym obrazu na podstawie zmieniających się danych geolokalizacyjnych przez urządzenie mobilne, a więc o ograniczonej mocy obliczeniowej, stawia pod znakiem zapytania jakość i dokładność restytucji. Ponadto, obraz komponentu rzeczywistego wyświetlany na urządzeniu mobilnym jest mniej naturalny niż postrzegany bezpośrednio, zwłaszcza że stanowi tylko kopię obrazu znajdującego się w polu widzenia obserwatora, wykraczającym poza monitor urządzenia. Znaczenie z punktu widzenia wierności przekazu informacji, zwłaszcza o skali obiektu, może mieć dobór stanowisk obserwacyjnych (Dordevic \& Vujic 2010).

\section{RESTYTUCJA ILUZORYCZNA ZA POMOCA ŚRODKÓW OPTYCZNYCH}

\subsection{Założenia}

Intencją autorów nie jest dokładne odwzorowanie usuniętych z przestrzeni obiektów architektonicznych, a jedynie przekazanie informacji o ich lokalizacji, rozmiarach oraz zarysie kształtu. Obserwator powinien postrzegać przede wszystkim otaczające go środowisko rzeczywiste, na którego tle mniej wyraźnie zarysowuje się obraz istniejących niegdyś obiektów - determinantów utraconego krajobrazu. Uznano, że dla tak rozumianej restytucji iluzorycznej, środki optyczne posiadają przewagę nad środkami elektronicznymi.

Przyjmuje się, że obraz komponentu wirtualnego powinien być przezroczysty lub półprzezroczysty, aby nie przesłaniał istniejących budynków oraz poruszających się osób lub pojazdów. Ruch ten może mieć miejsce w odległości od obserwatora większej niż oddalenie restytuowanego obiektu lub w przestrzeni pomiędzy obserwatorem a obiektem. Brak przejrzystości obrazu komponentu wirtualnego może zniweczyć iluzję. Korzystny wpływ powinno mieć zastosowanie środków generujących obraz stereoskopowy.

Ustalono, że w przeprowadzanym eksperymencie podstawową formą obrazu komponentu wirtualnego będzie reprezentacja linearna. Bardzo stonowane wypełnienie dopuszczono uznając, że może oddziaływać pożytecznie na wyobrażenie bryłowatości obiektu. Zrezygnowano z oznaczania linii niewidocznych. Ich obecność przeciwdziała dostrojeniu zmysłu wzroku obserwatora do prawidłowego postrzegania oglądanej sceny. Obraz komponentu wirtualnego powinien być monochromatyczny by zróżnicowaniem barwnym nie wprowadzał dodatkowych trudności percepcyjnych. Przedstawiony w odcieniach szarości będzie budził skojarzenia z czarno-białymi fotografiami, utożsamiającymi przeszłość.

Ustalono, że rzuty komponentu wirtualnego będą konstruowane bezpośrednio w oparciu o zasadę rzutowania środkowego, przy zastosowaniu programu AutoCAD. W wirtualnej przestrzeni zostaną utworzone modele restytuowanych obiektów, modele obiektów kalibrujących widok, tło rzutu środ- 
kowego oraz położenie oka obserwatora. Przyjęto, że znajduje się ono 1,5 m nad podłożem. Rzut odpowiadający widokowi jednoocznemu jest określony przez punkty przebicia tła pękiem prostych rzutujących poprowadzonych z oka w kierunku wierzchołków modelu. Dla odwzorowania stereoskopowego konstrukcję należy powtórzyć, przesuwając środek drugiego rzutowania względem środka pierwszego rzutowania w kierunku poziomym i równoległym do tła o odległość $65 \mathrm{~mm}$, uznawaną za równą oddaleniu źrenic u ludzi dorosłych (Mączyńska-Frydryszek et al. 1991).

\subsection{Restytucja monoskopowa}

Restytucja monoskopowa polega na umieszczeniu obrazu komponentu wirtualnego na przezroczystej tablicy. Odległość pomiędzy obserwatorem a tablicą powinna być ustalona tak, aby rysunek mieścił się na wygodnym formacie A4 i równocześnie znajdował się cały w środkowym polu widzenia, które wg (Mączyńska-Frydryszek et al. 1991) obejmuje kąt wierzchołkowy o mierze $40^{\circ}$. Ograniczenie rozmiaru obrazu komponentu wirtualnego ma zapobiec niezgodności punktów zbiegu uzyskanych na drodze konstrukcji opartej na rzutowaniu środkowym z punktami zbiegu percypowanymi bezpośrednio. Pojawia się ona wtedy, kiedy obserwator jest zmuszony poruszać gałkami ocznymi, nie mogąc objąć całego interesującego go wycinka przestrzeni jednym spojrzeniem (Strzemiński 1958).

Obraz powinien być oglądany jednym okiem. Po to, aby odbierane wrażenie usytuowania oraz rozmiarów restytuowanego obiektu było zgodne z prawdą, konieczne jest odwzorowanie wybranych fragmentów aktualnego otoczenia, w celu kalibracji obrazu. Pomocniczo, obserwatorowi powinno się wskazywać miejsce, na którym powinien stanąć.

\subsection{Restytucja stereoskopowa}

\subsubsection{Zastosowanie anaglifów}

Anaglify są to rysunki dostarczające wrażenia trójwymiarowości podczas oglądania za pomocą specjalnych okularów. Wrażenie jest osiągane dzięki temu, że rysunek składa się z rzutów odrębnych dla lewego i prawego oka. Każdy z nich jest wykreślony linią o innym kolorze, a szkła okularowe zabarwione każde na inny kolor, pełnią rolę filtrów wygaszających barwy nie adresowane do określonego oka. Jednym z zastosowań anaglifów, wynalezionych przez Wilhelma Rollmanna jeszcze w 1853 roku (Kaenders \& Weiss 2017), jest wspomaganie nauczania geometrii wykreślnej. Niektórzy autorzy dołączali do swoich podręczników (Otto \& Otto 1980, Przewłocki 1983) zestawy anaglifów w celu ułatwienia czytelnikom zrozumienia mało przystępnych konstrukcji planimetrycznych.

Działanie filtrów w okularach do anaglifów oparte jest na teorii barw (Drew \& Meyer 2013). Wg teorii addytywnej, przestrzeń barw, określana skrótem RGB, jest opisana za pomocą trzech barw elementarnych: czerwonej (ang. red -R), zielonej (ang. green - G) i niebieskiej (ang. blue - B). Intensywność każdej z nich określana jest liczbą całkowitą z przedziału $\langle 0,255\rangle$. Mieszanina barw R, G i B o wartościach 255 każda, daje światło białe. Można je uzyskać również w rezultacie połączenia tylko dwóch barw: pierwszej o wartościach $R=x, B=y, G=z$ oraz drugiej o wartościach $R=255-x, B=255-y, G=255-z$. Para takich barw to barwy komplementarne (Rzepińska 1966). Zastosowanie filtra barwnego powoduje odfiltrowanie światła o barwie filtra oraz absorpcję światła o barwie komplementarnej do barwy filtra (Weissenbock \& Symeonidou 2019).

Addytywna teoria barw odnosi się do mieszania świateł. Mieszanie barw w druku odbywa się zgodnie z substraktywną teorią barw (Drew \& Meyer 2013). W przestrzeni barw wg tej teorii określanej jako CMYK, barwami elementarnymi są cyan (C), magenta (M), żółty (ang. yellow - Y) oraz czarny $(\mathrm{K})$. Intensywność poszczególnych barw określana jest liczbami całkowitymi z przedziału $<0,100\rangle$. Dowolnie wybraną barwę można uzyskać także bez udziału barwy czarnej, ponieważ jest ona połączeniem barw C, M i Y o wartościach 100 każda. Pojęcie barw komplementarnych jest analogiczne jak w modelu RGB. Dla każdej z barw konstytuujących przestrzeń barw RGB można określić ekwiwalentne barwy w przestrzeni CMYK oraz odwrotnie. W Internecie dostępne są kalkulatory umożliwiające przeliczenia liczbowe (RapidTables). W kontekście anaglifów, możliwe jest 
określenie barw wydruku adekwatnych do zastosowanych filtrów okularowych. W praktyce, kolory oparte na modelu CMYK wykazują dość znaczną rozbieżność z odpowiednikami z modelu RGB.

W najczęściej stosowanym wariancie techniki anaglifowej rzut dla lewego oka jest wykreślony kolorem błękitnym ( $C=100, M=0, Y=0)$, a rzut dla prawego oka - kolorem czerwonym $(C=0, M=100$, $Y=100)$. Do oglądania rysunku stosowane są okulary, $w$ których lewy filtr jest czerwony $(R=255$, $\mathrm{G}=0, \mathrm{~B}=0)$, a prawy błękitny $(\mathrm{R}=0, \mathrm{G}=255, \mathrm{~B}=255)$. Parami barw komplementarnych są barwy obu filtrów, barwy obu rzutów oraz pary składające się z barwy filtra i barwy dedykowanego mu rzutu. W ten sposób, każdym okiem można dostrzec tylko rzut wykreślony kolorem innym niż kolor filtra przez który oko patrzy. Sumą koloru filtra i koloru widzianego przez ten filtr rysunku, jest zgodnie z substraktywną teorią barw zawsze kolor czarny. Rysunek dostarczający wrażenia trójwymiarowości jest widoczny jako czarny i znajduje się pośrodku pomiędzy rzutami wykreślonymi w kolorach czerwonym i błękitnym, które pozostają niewidoczne (Ryc. 1).

Problemem, który stwarza duże trudności jest pojawianie się tzw. duchów, czyli obrazów tych rzutów, które powinny być odfiltrowane przez odpowiedni filtr. Duchy pojawiają się w miejscach wykreślonych rzutów, z tym że są od nich mniej wyraźne, a także mniej wyraźne niż obraz przestrzenny. Współtworzą z nim jednak triadę obrazów, przez co utrudniają obserwatorowi koncentrację na percypowaniu właściwego z nich. Duchy są efektem zmiany barwy filtra poddanego działaniu światła w kierunku barwy białej. Oznacza to, że w barwie filtra wzrastają wartości barw komplementarnych do barwy RGB właściwej dla materiału zastosowanemu w filtrze, co oznacza, że barwy z modelu CMYK, które powinny być odfiltrowane, nie są odfiltrowane całkowicie.

Pewnym sposobem na rozwiązanie problemu duchów jest technika, w której dobór barw filtrów i rzutów jest dokonany tak, aby przez filtr czerwony była widoczna linia czerwona, zaś przez filtr niebieski - linia o barwie niebieskiej, przy równoczesnym braku widzialności linii niebieskiej przez filtr czerwony oraz czerwonej przez filtr niebieski. Realizacja tej metody wymaga, aby rzuty dla lewego i prawego oka nie znajdowały się na białym tle, ale tle, którego barwa jest odpowiednio dobraną mieszaniną barw $\mathrm{C}, \mathrm{M}$ oraz $\mathrm{Y}$. Zeszyt $\mathrm{z}$ anaglifami respektującymi takie założenia został dołączony do podręcznika (Otto \& Otto). Zastosowane zostały tam okulary z czerwonym filtrem dla prawego oka $(R=255, G=0, B=0)$ oraz niebieskim $(R=0, G=0, B=255)$ dla lewego. Ponieważ filtr czerwony absorbuje tylko barwę $C$, a filtr niebieski - wyłącznie barwę $Y$, rzuty muszą być wykreślone liniami, których barwy oprócz odfiltrowywanych składowych M i Y dla barwy czerwonej oraz C i M dla barwy niebieskiej, wykazują szczątkową obecność składowych absorbowanych: $\mathrm{C}$ w barwie czerwonej oraz $\mathrm{Y}$ w barwie niebieskiej. Faktycznie ani filtr czerwony nie odfiltrowuje barwy $C$, ani filtr niebieski barwy $Y$, a tylko substraktywne zmieszanie barw filtrów i ww. składowych powoduje, że niepożądane obrazy rzutów stają się nieodróżnialne od tła. W tej technice problem duchów traci na znaczeniu dlatego, że jeżeli nawet tworzą się one na skutek „prześwietlenia” filtrów, to ich barwa jest upodobniona do barwy tła (Ryc. 1).

Wykorzystanie anaglifów do projekcji komponentu wirtualnego w rzeczywistości rozszerzonej wymaga zastosowania analogicznego środka technicznego jak dla restytucji monoskopowej, tzn. przezroczystej tablicy, na której umieszczone zostaną pary barwnych rzutów obiektu. Uwagi wymienione w punkcie 3.2 nt. pozycji obserwatora i konieczności fragmentarycznego odwzorowania obiektów z otoczenia znajdują również zastosowanie. Ze względu na rolę barw oraz transparentność materiałów, jakość restytucji może dodatkowo zależeć od warunków ekspozycji, wynikających m.in. ze stanu nasłonecznienia.

\subsubsection{Zastosowanie stereoskopu}

Stereoskop dostarcza wrażenia trójwymiarowości ponieważ podobnie jak w anaglifach okiem lewym i prawym oglądane są inne, specjalnie przygotowane obrazy. Znajdują się one blisko oczu, a budowa stereoskopu uniemożliwia obserwowanie okiem lewym obrazu przeznaczonego dla oka prawego i odwrotnie. Wrażenie, że oba obrazy położone są w tym samym miejscu jest osiągane dzięki zastosowaniu soczewek załamujących promienie światła. Stereoskop wynaleziony przez Charlesa Weathstone'a w 1832 roku (Blundell 2011) i zdobył sobie dużą popularność w fotoplastykonach - urządzeniach umożliwiających prezentację serii obrazów stereoskopowych równocześnie szerszej publiczności. 
Adaptacja tradycyjnego stereoskopu do rzeczywistości rozszerzonej wymaga, aby materiał, na którym znajduje się para obrazów komponentu wirtualnego był przezroczysty. W związku z koniecznością zastosowania soczewek, łączne percypowanie tych obrazów z obrazem środowiska rzeczywistego nie jest możliwe bez rozbudowania urządzenia o dodatkowy układ optyczny. Tam gdzie w tradycyjnym stereoskopie umieszczone są nieprzezroczyste rysunki odrębne dla lewego i prawego oka, w urządzeniu adaptowanym powinien znaleźć się ekran z materiału półprzezroczystego, na którym wyświetlany byłby obraz środowiska rzeczywistego, a zarazem wykreślony obraz komponentu wirtualnego.

Schemat stereoskopu zaadaptowanego wg powyższych założeń przedstawiono na Ryc.2. Para soczewek $S_{1}$, odwraca i pomniejsza odrębne obrazy oglądane lewym i prawym okiem, które następnie zostają odwrócone oraz powiększone za pomocą soczewek $S_{2}$. Opisany efekt zostaje osiągnięty, jeżeli soczewki $\mathrm{S}_{1}, \mathrm{~S}_{2}$ i $\mathrm{S}_{3}$ oraz ekran są rozmieszczone w odległościach spełniających warunki wynikające z podstawowych zasad optyki geometrycznej (Hecht 2012), wyjaśnione na rysunku w funkcjach ogniskowych soczewek oznaczonych odpowiednio $f_{1}, f_{2}$ i $f_{3}$. Na ich dobór a również wpływ założony wstępnie rozmiar urządzenia. Obrazy przekształcone przez soczewki $S_{2}$ są wyświetlane na ekranie z materiału półprzezroczystego, na którym znajdują się obrazy komponentu wirtualnego. Nakładające się rzeczywiste obrazy obu komponentów rzeczywistości rozszerzonej są następnie postrzegane przez obserwatora analogicznie jak w tradycyjnym stereoskopie.

\section{OPIS PRZEPROWADZONYCH BADAŃ}

\subsection{Restytucja figury geometrycznej we wnętrzu - kalibracja metody}

W pierwszej fazie eksperymentu restytucji iluzorycznej poddano sześcian o długości krawędzi równej $1 \mathrm{~m}$. Restytucji dokonywano we wnętrzu, ustawiając obserwatora twarzą w kierunku przeszklonej ściany, po to by możliwie upodobnić warunki oświetleniowe do panujących w przestrzeni otwartej. Tablicę ustawiono $\mathrm{w}$ odległości $5 \mathrm{~m}$ od najbliższej krawędzi sześcianu, a obserwatora w odległości $0,55 \mathrm{~m}$ przed tablicą. Rzut skonstruowano zgodnie z procedurą opisaną w punkcie 3.1. Według tej samej procedury skonstruowano rzuty do anaglifów, przesuwając środek drugiego rzutowania o $65 \mathrm{~mm}$ wzdłuż linii poziomej i równoległej do tablicy w stosunku do środka pierwszego rzutowania (Ryc. 3).

Próbę rozpoczęto od obrazu monoskopowego. W celu weryfikacji dokładności restytucji na podłodze pomieszczenia oznaczono kolorową taśmą kwadrat o boku $1 \mathrm{~m}$ (Rys. 4a). Wielkość rysunku wynikająca z położenia obiektu, tablicy i obserwatora okazała się trafna, a obawy opisane w punkcie 3.2 bezzasadne. Po zweryfikowaniu racjonalności metody rzut sześcianu uzupełniono o rzuty elementów otoczenia, w celu sprawdzenia czy kalibracja położenia obserwatora w oparciu o obrazy charakterystycznych linii w środowisku rzeczywistym jest wystarczająco dokładna. W zamierzonym zastosowaniu metody w przestrzeni architektonicznej miejsce położenia komponentu wirtualnego nie będzie bowiem zaznaczone. Również ta hipoteza została zweryfikowana pomyślnie (Ryc. 4b).

W dalszym toku, obserwacji poddano obrazy różniące się kolorem (czarny i czerwony), grubościami linii $(0,35,0,7$, i $1,0 \mathrm{~mm})$ oraz formą rysunku ograniczoną do postaci linearnej lub wzbogaconą o wypełnienie na poziomie 20,40 i $60 \%$. Ustalono, że rysunek w kolorze czarnym wywiera efekt bardziej korzystny niż rysunek w kolorze czerwonym. Spośród trzech grubości linii do dalszych eksperymentów wytypowano linię o grubości $0,7 \mathrm{~mm}$. Rysunek $z$ wypełnieniem uznano za dobrą alternatywę dla rysunku linearnego, typując do eksperymentu w przestrzeni architektonicznej wypełnienie na poziomie $40 \%$.

Obraz monoskopowy uwzględniono w eksperymencie ponieważ nie wymaga on dysponowania specjalnymi okularami, przez co w warunkach przestrzeni publicznej, nie ograniczy dostępu nikomu z zainteresowanych, jednak lepszych efektów oczekiwano od obrazów stereoskopowych. Dla tych samych co powyżej parametrów określających wzajemne położenie obiektu, tablicy i obserwatora, przeprowadzono próbę restytucji iluzorycznej opartą na anaglifach. Rzuty dla lewego i prawe- 
go oka wykreślono liniami o grubości $0,7 \mathrm{~mm}$, w kolorach wynikających z zależności opisanych w punkcie 3.3.1.

Anaglify wykonane zgodnie z założeniami dla pierwszego wariantu metody, tj. wykreślone na bezbarwnym tle liniami w kolorach błękitnym i czerwonym, okazały się zadowalające tylko w ograniczonym stopniu. Pierwszą z komplikacji okazała się trudność w „dostrojeniu” narządu wzroku, na jaką napotykały niektóre z postronnych osób poproszonych o wzięcie udziału w eksperymencie. Problem polega na tym, że ostrość widzenia powinna być nastawiona na obserwację obiektu w miejscu jego domniemanej lokalizacji. Osoby oznajmujące o niemożności dostrzeżenia obrazu stereoskopowego prawdopodobnie koncentrowały się na obserwacji tablicy, na której znajdowały się rzuty sześcianu. Drugą komplikacją jest pojawianie się duchów. Duchy są skutkiem nie tylko zmiany barwy filtrów podświetlonych światłem otoczenia, ale również zmiany barwy samego rysunku, który jest wykreślony na materiale transparentnym.

Przeprowadzono także próbę z anaglifami sporządzonymi na ciemnym tle. Sam fakt, że tło nie jest bezbarwne, w opinii autorów nie stanowi przeszkody. Tło wydrukowane za pomocą drukarki na przezroczystej folii, okazało się jednak nie być na tyle transparentne, aby w umożliwić zadowalające postrzeganie otoczenia znajdującego się za tablicą z anaglifami. Pojawia się trudność ze skorelowaniem obrazu komponentu wirtualnego z obrazem środowiska rzeczywistego. Próbę powtórzono posługując się anaglifami wykreślonymi na tle o barwie mniej intensywnej, lecz nie stwierdzono poprawy jakości rezultatu. Użycie folii barwnej zamiast bezbarwnej nie może być brane pod uwagę, ponieważ barwa folii wpłynęłaby zarazem na barwy wydrukowanych na niej anaglifów. Również w tym wariancie anaglifów mankamentem jest obecność duchów. Ich pojawianie się mimo zabarwionego tła to skutek zmiany barwy tła w rezultacie podświetlenia światłem otoczenia.

Doświadczenie z projekcją obrazu komponentu wirtualnego za pomocą stereoskopu nie przyniosło dobrych rezultatów ze względu na niewystarczającą przejrzystość ekranu wykonanego z kalki technicznej oraz niską jasność obrazu, wynikającą z zastosowanego układu optycznego. Układ ten został zrealizowany zgodnie z rysunkiem 2 . Zastosowano soczewki $S_{1}$ o ogniskowej $30 \mathrm{~mm}$ oraz $\mathrm{S}_{2}$ o ogniskowej $15 \mathrm{~mm}$. W roli soczewek $\mathrm{S}_{3}$ zastosowano typowe soczewki używane w kartonowych stereoskopach oraz urządzeniach znanych jako Google Cardboard i przyjęto identyczną jak w tych urządzeniach odległość $\mathrm{d}_{31}$ wynoszącą $70 \mathrm{~mm}$. Dobór parametrów układu optycznego został uwarunkowany dostępnością soczewek oraz założonym wstępnie przybliżonym rozmiarem urządzenia.

\subsection{Weryfikacja eksperymentu w przestrzeni architektonicznej}

Wnioski z wizualizacji sześcianu zostały zweryfikowane w przestrzeni architektonicznej. Postanowiono, że przedmiotem restytucji iluzorycznej będzie tzw. Zajazd pod Czerwoną Bramą - budynek zlokalizowany w Rzeszowie przy ul. Grunwaldzkiej, wyburzony w latach 50-tych XX wieku w związku z budową w sąsiedztwie gmachu Urzędu Wojewódzkiego (UW). Ponieważ wyburzenia Zajazdu dokonano dopiero po zakończeniu budowy UW, dostępne są fotografie przedstawiające współistniejące oba budynki (Ryc. 5). To okoliczność ułatwiająca restytucję, kolejną jest pozostawanie w miejscu Zajazdu pustej przestrzeni. Wybór Zajazdu uznano za trafny również z tego powodu, że jego forma architektoniczna przy względnej prostocie była zarazem dość oryginalna.

Model budynku skonstruowano w programie AutoCAD. Usytuowanie ustalono na podstawie mapy pochodzącej sprzed wzniesienia budynku UW. Ponieważ przyjęto, że odniesieniem dla obserwatora będzie właśnie budynek UW, konieczne było nałożenie mapy archiwalnej na aktualną (Ryc. 6). Było to łatwe ze względu na obecność w sąsiedztwie obiektów, które na przestrzeni lat nie uległy zmianie. Pozostałe wymiary budynku odtworzono na podstawie fotografii, kreśląc na niej konstrukcję perspektywy w oparciu o dane z planu budynku (Grochowski 2010). Procedura została wyjaśniona na Ryc. 7. Model budynku UW powstał w oparciu o aktualną mapę, pomiary wysokościowe dokonane in situ oraz pomiary z numerycznego modelu pokrycia terenu (NMPT).

Dysponowanie powiązanymi przestrzennie trójwymiarowymi modelami budynków Zajazdu oraz UW umożliwia konstrukcję rzutów obu obiektów z dowolnego punktu przestrzeni. Wybrano dwa takie punkty, dostarczające zasadniczo odmiennych wyglądów Zajazdu (Ryc. 8). Z każdego z nich 
przeprowadzono restytucję iluzoryczną metodami, jakimi posłużono się do wyżej opisanej restytucji sześcianu. Eksperyment powtórzono przy różnych warunkach oświetleniowych. Obrazy komponentu wirtualnego były poddawane korektom uwzględniającym spostrzeżenia dokonane podczas prób poprzednich.

\subsection{Opis rezultatów}

Stwierdzono, że czynnikiem wpływającym na jakość restytucji iluzorycznej w terenie otwartym sa warunki oświetleniowe. Zwłaszcza dla metod z zastosowaniem transparentnej tablicy niekorzystne jest ostre nasłonecznienie. W zależności od położenia słońca przezroczystość materiału ulega obniżeniu lub pojawiają się refleksy świetlne (Ryc. 9a).

Zmienność warunków oświetleniowych jest szczególnie dolegliwa dla anaglifów. Na skutek rozjaśnienia kolorów pod wpływem światła pogłębia się niezgodność kolorystyki filtrów i rysunku, a tym samym wzrasta wyrazistość duchów. Korzystniejsze rezultaty są osiągane jeżeli stanowisko obserwacyjne znajduje się w cieniu, podczas zachmurzenia, lub w porze ograniczonej projekcji światła słonecznego. Obraz 3D w kolorze czarnym jest wyraźniejszy na jasnym tle. Kontrast pomiędzy nim a tłem jest wtedy większy niż między duchami a tłem, przez co nie odwracają one uwagi od obrazu trójwymiarowego (Ryc. 9b).

Pomimo tego, że anaglify na ciemnym tle utrudniają postrzeganie środowiska rzeczywistego, zasada stanowiąca ich podstawę może być wykorzystana na materiale bezbarwnym. Dobre efekty uzyskiwane są wtedy, kiedy rolę tła przejmuje ciemno zabarwiona elewacja budynku lub grupa zacienionych drzew. W takim przypadku jasny obraz stereoskopowy kontrastuje $z$ tłem, a duchy zbliżone kolorem do tła nikną w nim. Różnica kontrastów sprawia, że uwaga obserwatora zostaje skupiona na obrazie trójwymiarowym.

Czynnikiem wpływającym na jakość percepcji jest usytuowanie elementów, na których oparta jest kalibracja położenia obserwatora. Powinny być wyraziste w percypowanej przestrzeni, a zarazem położone w pobliżu środka pola widzenia. W przeciwnym razie obserwator skupia uwagę na poszukiwaniu elementów kalibrujących, nie na obiekcie stanowiącym przedmiot restytucji iluzorycznej. Warunkami sukcesu są ustawienie się we właściwej odległości od tablicy oraz umiejscowienie oczu na właściwej wysokości. Mimo, że miejsce, które ma zająć obserwator można oznaczyć, prawidłowa odległość stóp od podstawy tablicy nie gwarantuje takiej samej odległości oczu obserwatora od obrazu, ponieważ człowiek może przyjąć postawę niedokładnie pionową. Również usytuowanie oczu na odpowiedniej wysokości sprawia trudność osobom o zróżnicowanym wzroście.

Mimo kompetencji autorów, postrzeganie przez nich obrazu stereoskopowego nie było natychmiastowe. Spostrzeżenie głębi przestrzennej wymaga dostrojenia narządu wzroku, zaś koncentracja na problemie trójwymiarowości osłabia natężenie uwagi na elementach kalibrujących położenie obserwatora. Z tego powodu metody, w których położenie oczu obserwatora oraz obrazu komponentu wirtualnego nie są jednoznacznie skorelowane, ustępują przed zastosowaniem stereoskopu, w którym każde oko przylega bezpośrednio do okularu urządzenia, zajmującego w przestrzeni stałą pozycję.

Eksperyment ze stereoskopem powtórzono w przestrzeni otwartej. Przy dobrym nasłonecznieniu, kiedy obraz środowiska rzeczywistego stawał się jasny, okazywał się częściowo widoczny. Trudne okazało się kalibrowanie położenia instrumentu, zwłaszcza ze względu na brak w tym obrazie wyraźnych kontrastów. Proces kalibracji jest jednak jednorazowy, a ponadto może być wspomagany metodami geodezyjnymi. Autorzy dysponowali stereoskopem zamocowanym na statywie fotograficznym (Ryc. 10), mniej stabilnym niż urządzenie w formie obiektu małej architektury. Użytkownik zwolniony z potrzeby kalibracji położenia, mógłby skupić się wyłącznie na akomodacji oczu do postrzeżenia obrazu trójwymiarowego. Częściową nieprzejrzystość obrazu można rozpatrywać nawet $w$ kategorii zalety. Wzmacnia ona wrażenie nierealności przenikania się niejednoczesnych faz zagospodarowania przestrzeni, które jest przecież nierealne.

\section{WNIOSKI DO DALSZYCH BADAŃ}

Rezultaty uzyskane podczas eksperymentów dostarczają wskazówek do dalszych badań. W pierwszej kolejności należy wyeliminować mankamenty wynikające z nieodpowiednich parame- 
trów urządzeń, jakości materiałów, kolorystyki wydruków itp. Poprawa jakości obrazów może i powinna stać się punktem wyjścia do badań na większej grupie osób, które należy poprosić o ocenę sposobów restytucji iluzorycznej, najlepiej w jakiejś mierzalnej skali. Jak wspomniano, spostrzeżenie obrazu trójwymiarowego kompilowanego z dwóch obrazów dwuwymiarowych nie jest automatyczne nawet dla osób o rozwiniętych predyspozycjach przestrzennych. Restytucja iluzoryczna jako metoda edukacyjna jest adresowana również do mniej przygotowanego odbiorcy. W związku z tym, ważne jest uzyskanie miarodajnej opinii przed decyzją o zastosowaniu w przestrzeni publicznej.

Najtrudniejszy do rozwiązania jest problem duchów na anaglifach. Jest on powszechnie podkreślany w literaturze (Ideses \& Yaroslavsky 2005, Woods et al. 2013), a nawet najdokładniejsze dostosowanie kolorystyki filtrów okularowych oraz rysunku może przynieść skutek satysfakcjonujący tylko w ściśle określonych warunkach oświetleniowych. Remedium można poszukiwać w technologii opartej na zastosowaniu przezroczystego ekranu, na którym barwy anaglifów byłyby korygowane przez odpowiedni program z barwami filtrów okularowych w czasie rzeczywistym (Kim et al. 2011). Prowadzenie badań w tym zakresie wykracza poza możliwości techniczne oraz kompetencje autorów.

Autorzy preferują stosowanie XIX-wiecznych technik optycznych do wizualizowania obiektów, których istnienie jest zakotwiczone w przeszłości. Brak jest powodów powstrzymujących przed implementacją również nowoczesnych technologii, zwłaszcza o wyższej skuteczności. Poszukiwanie najdoskonalszych metod i narzędzi restytucji iluzorycznej ma znaczenie również w kontekście wizualizacji in situ obiektów projektowanych, w celu prewencyjnego określania ich wpływu na zastany krajobraz architektoniczny.

\section{BIBLIOGRAPHY}

Azuma R., 1997, A survey of augmented reality, Teleoperators and Virtual Environments No. 4, 355-385.

Blundell B., 2011, 3D Displays and Spatial Interaction: Exploring the Science, Art, Evolution and Use of 3D Technologies, Vol. 1: From Perception to Technology, Walker \& Wood, Auckland.

Caudell T. P., Mizell D. W., 1992, Augmented reality: an application of heads-up display technology to manual manufacturing processes. Proceedings of the Twenty-Fifth Hawaii International Conference on System Sciences, Vol.2, 659-669.

Dordevic D., Vujic G., 2010, Visual Illusion of the change of the size of architectural and urban objects observed upon a change of the observer's distance: parameters that influence it phenomenologically, SPATIUM International Review, No. 22, 38-46.

Drew J. T., Meyer S. A., 2013, Zarządzanie kolorami, Wydawnictwo ARKADY, Warszawa.

Grochowski B., 2010, Geometria wykreślna z perspektywą stosowaną, Wyd. Naukowe PWN, Warszawa.

Hecht E., 2012, Optyka, Wydawnictwo Naukowe PWN, Warszawa.

Ideses I., Yaroslavsky L. 2005, Three methods that improve the visual quality of colour anaglyphs, Journal of Optics A: Pure and Applied Optics, No. 7, 755-762.

Ingarden R., 1958, Studia z estetyki T.2, Państwowe Wydawnictwo Naukowe, Warszawa.

Kaenders R., Weiss Y., 2017, Historical methods for drawing anaglyphs in geometry teaching. Proceedings of CERME 10, Dublin, hal-01938813.

Kim J., Kim Y., Hong J., Park G., Homg K., Min S-W. Lee B., 2011, A full-colour anaglyph three-dimensional display system using active colour filter glasses, Journal of Information Display, Vol. 12, No 1, 37-41.

Konik R., 2011, Czy nowe media są faktycznie nowe? Kilka uwag na marginesie sporu o definicje nowych mediów. Dyskurs, Nr 12, 296-315.

Konopacki J., 2014a, Rozszerzona rzeczywistość jako narzędzie wspomagające procesy analitycznodecyzyjne w architekturze i planowaniu przestrzennym. Przestrzeń i Forma Nr 21, 89-108.

Konopacki J., 2014b, Wirtualne rekonstrukcje założeń architektoniczno-krajobrazowych - technologia rozszerzonej rzeczywistości, Czasopismo techniczne: Architektura, Nr 5-A, 97-112.

Mazur R., Piekarski M., Filipowski Sz., 2019, Augmented reality as a component of participation in shaping the architectural space, Architectus, Nr 2(58), 85-94. 
Mączyńska-Frydryszek A., Jaskólska-Klaus M., Maruszewski T., 1991, Psychofizjologia widzenia, Państwowa Wyższa Szkoła Sztuk Plastycznych w Poznaniu, Poznań.

Millgram P. H., Takemura H., Utsumi A., Kishino F., 1994, Augmented reality: a class of displays on the reality-virtuality continuum. Telemanipulator and Telepresence Technologies No., 282-292.

Otto F., Otto E., 1980, Podręcznik geometrii wykreślnej, Państwowe Wydawnictwo Naukowe, Warszawa.

Piekarski M., 2018, Potencjał zastosowań rzeczywistości rozszerzonej w restytucji oraz konserwacji zapobiegawczej dziedzictwa architektonicznego. Architektura w krajobrazie: Harmonia-Kompromis-Konflikt (red. W. Kobylińska-Bunsch), Instytut Historii Sztuki Uniwersytetu Warszawskiego, Warszawa, 339-352.

Przewłocki S., 1982, Geometria wykreślna w budownictwie, Arkady, Warszawa.

RapidTables https://www.rapidtables.com/convert/color/rgb-to-cmyk.html, dostęp/access 1.07.2021

Rzepińska M., 1966, Studia z teorii i historii koloru, Wydawnictwo Literackie, Kraków.

Strzemiński W., 1958, Teoria widzenia, Wydawnictwo Literackie, Kraków.

Tomaszewski A., 2012, Ku nowej filozofii dziedzictwa, Międzynarodowe Centrum Kultury, Kraków.

Weissenbock R., Symeonidou I., 2019, Anatomy of Building. Introducing interactive RGB lenses for architectural data visualisation, Proceedings of eCAADe, 739-748.

Woods A. J., Harris Ch. R., Leggo D. B., Rourke T M., 2013, Characterizing and Reducing crosstalk in printed anaglyph stereoscopic 3D images, Optical Enginneering 52(4), 043203.

\section{AUTHOR'S NOTE}

Maciej Piekarski is a graduate of construction at the Faculty of Civil Engineering of the Warsaw University of Technology. He has doctorate degree in the discipline of construction and postdoctoral degree in the discipline of architecture and urban planning. He is employed as an associate professor in the group of research and teaching staff. His research interests include the morphology of building structures, as well as the issues of public space as a carrier of urban identity.

Ewa Kulpińska is a graduate of architecture at the Faculty of Civil and Environmental Engineering and Architecture of the Rzeszów University of Technology. She is employed as an research and teaching assistant. Her research interests concern the issues of supplementary building and greens in the areas of downtown development.

Anna Prokop is a graduate of construction and architecture at the Faculty of Civil and Environmental Engineering and Architecture of the Rzeszów University of Technology. She is employed as an research and teaching assistant. Her research interests include BIM modelling and modern forms of analysis and protection of cultural heritage objects.

\section{O AUTORACH}

Maciej Piekarski jest absolwentem kierunku budownictwo na Wydziale Inżynierii Lądowej Politechniki Warszawskiej. Posiada stopnie naukowe doktora w dyscyplinie budownictwo oraz doktora habilitowanego $w$ dyscyplinie architektura i urbanistyka. Jest zatrudniony na stanowisku profesora uczelni w grupie pracowników badawczo-dydaktycznych. Jego zainteresowania naukowe obejmują zagadnienia morfologii konstrukcji budowlanych, a także tematykę przestrzeni publicznej, jako nośnika tożsamości miejskiej.

Ewa Kulpińska jest absolwentką kierunku architektura na Wydziale Budownictwa, Inżynierii Środowiska i Architektury Politechniki Rzeszowskiej. Jest zatrudniona na stanowisku asystenta badawczo-dydaktycznego. Jej zainteresowania naukowe dotyczą zagadnień zabudowy uzupełniającej oraz zieleni na obszarach zabudowy śródmiejskiej.

Anna Prokop jest absolwentką kierunków budownictwo oraz architektura na Wydziale Budownictwa, Inżynierii Środowiska i Architektury Politechniki Rzeszowskiej. Jest zatrudniona na stanowisku asystenta badawczo-dydaktycznego. Jej zainteresowania naukowe obejmują modelowanie BIM oraz nowoczesne formy analizy i ochrony obiektów dziedzictwa kulturowego.

Contact | Kontakt: mgpiekar@prz.edu.pl, e.kulpinska@prz.edu.pl, a.prokop@prz.edu.pl 